\title{
Commanditaire Vennootschap: An Indonesian Micro Small Medium Enterprise, Environmental Crime Responsibility
}

\author{
Abdul Aziz Alsa \\ \{aziz.alsa@live.com\} \\ Universitas Diponegoro, Indonesia
}

\begin{abstract}
Commanditaire Vennootschap, a popular entity for micro small medium enterprise in Indonesia, is an incorporated business entity as a perpetrator of environmental crime is obliged to maintain the function of the environment and manage the pollutions or environmental damages. Pollutions or environmental damages caused by an economical content and will be increase as the progress of economical. It is a duty of every person to maintain the functions of the environment and manages the pollutions or environmental damages. The responsibility of an incorporate business entity to environmental protection and management may be convicted to the business entity, and also those who govern the environmental crimes and people who lead the offense. The incorporate responsibility in environmental crime may be convicted to the association and to the agents that consist by general partner and limited partner on a duty that caused a pollutions and environmental damages.
\end{abstract}

Keywords: Responsibility, Corporate, Commanditaire Vennootschap, Indonesian Micro Small Medium Enterprise, Environmental Protection and Management

\section{Introduction}

In general, there are three forms of corporate organization [1], namely sole proprietorship or sole trader, partnership and companies or corporations [2]. However, along with the development of the corporate structure within the partnership, a special form of partnership has developed, namely the Commanditaire Vennootschap [3] or Limited Partnership [4].

A business entity in the form of a Commanditaire Vennootschap is a business entity that is quite popular in Indonesian society. At least there are more than hundreds of thousands of business entities in the form of Commanditaire Vennootschap that have developed in Indonesia. This form of business entity originated in the Middle Ages in Europe which was formulated in the codification of the Napoleonic Code, and through the concordance of Dutch law which was then applied in the Dutch East Indies.

Indonesia and another countries categorize Commanditaire Vennootschap into unincorporated business entities [5]. Although this form of business entity is quite popular in Indonesia, there is no specific law that regulates business entities in the form of Commanditaire Vennootschap, in contrast to firms and civil associations (maatschap) and limited liability companies which already has clear arrangements so as to provide legal certainty. If studied further, Commanditaire Vennootschap is a special form of Firma. This is because the firm only 
has active partners, while in Commanditaire Vennootschap there are active and limited partners (sleeping partners) [6].

This paper discusses the existence of Commanditaire Venootschap in Indonesia, but without the applicable regulations. Although the existence of Commanditaire Venootschap is considered a lot in Indonesia, there are no regulations regarding Commanditaire Venootschap in Indonesia,Commanditaire Venootschap should be regulated in the Company Law 2007, but in reality, the Commanditaire Vennootschap regulation is only regulated in the Company Law 1995 which is no longer valid. The paper stresses the importance of Commanditaire Vennootshap regulation, without the clear regulations governing the Commanditaire Vennootschap will potentially create a legal vacuum and create confusion in determining criminal liability.

Commanditaire vennotschap is part of the community, this can be seen from the growth of this form of business entity in people's daily lives in running the economy. And the Indonesian government has given special attention to this form of business entity in the form of direct cash assistance during the Covid-19 pandemic outbreak, this is done by the government in order to encourage a better people's economy so that they contribute something useful for the benefit of people's lives.

In carrying out its function to encourage the economy, sometimes business entities also often take actions that are contrary to the provisions of the legislation, for example, the perpetrators of these business entities pollute and/or damage the environment. Business entities are often negligent in their obligations to manage the environment [7]. Environmental pollution and/or damage has increased along with the increase in industrial activities, so that the environment needs to obtain legal protection [8].

Criminal law contributes to providing legal protection for the environment. Policies in terms of the environment are not formulated in the form of legal norms, enforcement efforts in environmental law are carried out through criminal law and are more complementary than regulatory instruments [9].

In criminal law, the principle of Nullum Delictum nulla poena sine praevia lege poenali is known, which means that there is no punishment without a regulation which first states that the act is an offense which has a penalty for the offense [10]. It is stated that if there is a criminal act committed by a person based on an employment relationship or based on other relationships within the scope of work of the business entity, criminal sanctions are given to the giver of the order or the leader in the criminal act that occurred without regard to the offense being committed alone or together [11].

Commanditaire Vennootschap as a business entity that is popular as a micro, small and medium business [12] in Indonesia can be held accountable for environmental crimes that occur because of the business activities carried out by these business entities. The formulation is adopted by the Indonesian Criminal Code, if a crime occurs, the person who is asked to be held accountable is the person who committed the crime. So if the one who commits a criminal act is a corporation or business entity, then those who are accountable are the management of the corporation or its allies in the Commanditaire Vennootschap.

It will argued that the provisions of the Environmental Law require that everyone maintains environmental functions and controls environmental pollution and destruction, and is required to provide true and accurate information on environmental protection and management, maintain sustainable environmental functions, and standard criteria for environmental damage. It is argued that the Article 116 of the Environmental Protections and Management Act 2009 is a concept of criminal liability in the environmental field for corporations that commit criminal acts that cause environmental pollution and damage. 
It is argued that the responsibilities of the Commanditaire Vennootschap allies while the criminal of environmental protection and management committed. It also argued the justifications and excuses for the Commanditaire Vennootschap allies based of environmental crime that occurred within the scope of business activities Commanditaire Vennootschap.

\section{Research Method}

The methodology adopted in the current research is doctrinal, which emphasizes the legal propositions and doctrines. This methodology is founded upon the analytical, and critical study of statutes, its interrelationship and interpretation of statutes made by the judiciary. The research is conducted through investigating and using secondary sources including books, reviews of case law, statutes, articles and journals. Material collection shall include intensive library research and internet searches.

\section{Results and Discussion}

\subsection{Commanditaire Vennootschap in Environmental}

\subsubsection{Crimes Existence of Commanditaire Vennootschap in Indonesia}

One of the forms of non-legal entities is Commanditaire Vennotschap or better known to the Indonesian people as Commanditaire Vennotschap. This business entity is still growing and alive, especially for small and medium-sized businesses or businesses. And during this Covid19 pandemic, this form of individual business entity is popular among small and medium businesses. At least there are more than 161,303 business entities in the form of Commanditaire Vennootschap that have developed in Indonesia [13]. The simple management structure attracts Micro, Small and Medium Enterprises in Indonesia to run their business in the form of a Commanditaire Vennootschap.

Commanditer Vennootschap there are two types of allies, namely Complementary allies and Commanditaire allies. This means that the rights and obligations of an ally are determined by the function of the status whether as beherend or Commanditaire, and not because of the role(role) that is performed as the amount of control one has in the company. Thus, although the Articles of Association of the Commanditaire Vennootschap limit the authority of the managing partner in the management of the company, he is still a responsible partner, with the same rights and obligations as other responsible partners [3]. The liability of partners is only limited to the contribution [14], while The liability of the managing partner is not limited, meaning that the personal assets of the managing partner become collateral for the creditors of the Commanditaire Vennootschap [15].

\subsubsection{Obligations and Responsibilities of the Commanditaire Vennootschap Partners}

The main characteristic of a partnership, including the Commanditer Vennootschap partners, is the unlimited liability of the managing partners. In theory, this unlimited responsibility can be an attractive factor or an inhibiting factor as a form of business entity that develops in micro, small and medium enterprises. This unlimited liability on the one hand causes 
partners to face financial risks, but on the other hand provides certainty for clients to trust one partner in the capabilities of other partners [16].

As for the full responsibility imposed on the management partners, it is based on the opinion that whether it's good or bad, the progress of the partnership depends on their own efforts and leadership. Such a situation will change if a limited partnership partner intervenes in the organization and arrangement of the partnership [17].

There are 2 (two) types of partners in a limited partnership, namely management partners and limited partnership partners, resulting in two types of responsibilities, namely unlimited liability and limited liability. Personal liability means that creditors can claim partnership obligations not only from the partnership assets but also from the partners' personal assets. In other words, the contribution of the management partner provides a guarantee for the company's obligations; while limited liability means that the owner's responsibility for the company is only equal to the capital invested in the company. The owner's risk is not more than the money he has paid or has agreed to share. Owners with limited liability only fulfill agreed promises [3].

\subsubsection{Commanditaire Vennootschap as Perpetrators of Environmental Crimes}

Business entities that act as perpetrators of environmental crimes, not only business entities that can be prosecuted, but also a person (natuurlijk persoon). A person can be sued either as the one who gives orders/tasks or as a leader [18]. In other words, it can be said that a business entity in the form of a limited partnership is obliged to maintain the preservation of environmental functions and control pollution and/or environmental damage. Inability or failure to fulfil obligations without reasons that are objectively acceptable according to law, can certainly result in the birth of legal liability in the field of civil law and criminal law for legal subjects who are unable or fail to fulfil these obligations [19].

\subsubsection{Liability of the Commanditaire Vennootschap Entity in Environmental Crimes}

The criminal liability of a business entity can be requested from the business entity and or the person who gave the order to commit the crime or the person acting as the leader of the activity in the crime [11]. Criminal liability can also be imposed on a business entity if the environmental crime were committed by a person or legal subject who has a work relationship or other relationship to the entity, and its commit within the scope of work of the business entity. If its happen, the criminal sanction is directed to the giver of the order or the leader of the crime. The sanctions can be imposed to regardless of whether the criminal act is committed by the giver of the order or the leader of the crime by himself or with others [11].

The provisions in the Indonesian Environmental Law make the concept of corporate criminal liability in the environmental field imposed on a business entity and its management (in a limited partnership consisting of limited partnership and complementary partners) jointly, in terms of the activities and/or business of the corporation causing pollution and/or environmental damage [8].

The criminal liability of a business entity can be based on the following matters [20]:

a. On the basis of an integrated philosophy, that is, everything its will is measured on the basis

of balance, harmony and harmony between individual interests and social interests.

b. On the basis of the principle of kinship in Article 33 of the 1945 Constitution.

c. To eradicate anomie of success (success without rules).

d. For consumer protection.

e. For technological progress. 
In relation to criminal liability of corporations or business entities, according to VS Kanna, it was stated that there are three conditions that must be met for the existence of corporate criminal liability, namely; the agent commits a crime; the crime committed is still within the scope of its work and is carried out with the aim of benefiting the corporation or business entity [21].

Regarding the nature of limited partnership liability in Indonesian Criminal Law, there are several methods or formulation systems adopted by legislators, namely:

a. Allies of the board as the maker and allies of the responsible management.

b. The limited partnership entity is the maker and the limited partnership entity is responsible.

c. Limited partnership as the maker and also as the one in charge.

\subsubsection{Reasons for Eliminating the Crime for the Responsibility of the Commanditaire Vennootschap in Environmental Crimes}

Criminal law recognizes several reasons that can be used as the basis for judges not to impose penalties/criminals on the perpetrators or defendants who are brought to court because they have committed a crime. These reasons are called the reasons for the abolition of the crime. In fact, the perpetrator or defendant has fulfilled all the elements of a crime formulated in the criminal law regulations. However, there are several reasons that can cause the perpetrator to not be convicted, or to be excluded from the imposition of criminal sanctions as formulated in the said legislation, thus enabling people who have committed acts that have actually fulfilled the formulation of the offense, to be punished; and this is the authority given by law to judges [22].

The basis for eliminating the crime (strafuitsluitingsgronden) must be distinguished from the basis for the abolition of prosecution (verval van recht tot strafvordering). The first is determined by the judge by stating that the unlawful nature of the act of erasing or the error of the maker of the eraser is due to the provisions of laws and laws that justify the act or forgive the maker. In this case the right to sue the prosecutor remains, but the defendant is not sentenced. He must be charged with and separated from the basis for eliminating criminal prosecution, eliminating the right to sue the prosecutor, because of the provisions of the law [23]. From a dualistic point of view, the rationale for justification negates the unlawful nature of the act, and the defendant should be released, whereas if there is a basis for forgiveness, it means that the criminal act of the accused is proven, but the perpetrator of the offense is forgiven [23].

The partners of Commanditaire Vennootschap can submit a reason for eliminating criminal and free from criminal liability if they have carried out their obligations and responsibilities in carrying out the management of the company within its scope in good faith, full of responsibility, and also applying the principles of business judgment risk.

\section{Conclusion}

Criminal liability is everyone's responsibility for the crime they have committed. Criminal liability for business entities Commanditaire Vennootschap needs to be considered first the element of error that occurred (strict liability). Business actors can also be held accountable for criminal acts committed by other people who are within the scope of their business activities resulting in losses for others (vicarious liability). In the structure Commanditaire Vennootschap, criminal liability for criminal acts that occur is addressed to the management partners, however, 
limited partners can also be held accountable if they participate in managing the running of the business entity.

\section{References}

[1] R. W. Emerson, Bussiness Law, New York: Barron's Educational Series Inc, 2004.

[2] J. Maejier, A Modern European Company Law System Commentary on the 1976 Dutch Legislation, Neteherlands: Sitjhoff \& Noordhof International Publisher BV, 1978.

[3] Y. K. Dewi, Pemikiran Baru tentang Commanditer Vennotschap (CV), Jakarta: Badan Penerbit FHUI, 2011.

[4] S. Randazzo, "The Nature of Partnership in Roman Law," Australian Journal of Legal History, vol. 9 , p. 127, 2005 .

[5] S. Allen, Choice of entity from a state planning perspective, Colorado lawyer.

[6] Soekardono, Hukum Dagang Indonesia, Jakarta: Rajawali Pers, 1991.

[7] B. Wahono, Penegakan Hukum Lingkungan melalui Ketentuan-ketentuan Hukum Pidana, Jakarta: Mahkamah Agung RI, 2011.

[8] A. Syahrin, Ketentuan Pidana dalam UU No. 32 tahun 2009 tentang Perlindungan dan Pengelolaan Lingkungan Hidup, Jakarta: PT. SOFMEDIA, 2011.

[9] A. Syahrin, Asas-asas dan Penegakan Hukum Lingkungan Kepidanaan, Medan: Penerbit Pustaka Bangsa, 2002.

[10] E. Utrecht, Rangkaian Sari Kuliah Hukum Pidana I, Jakarta: UI Press, 1958.

[11] Indonesian Environmental Law.

[12] Indonesian Omnibus Law.

[13] Establishment of Economic BPS Statistics Indonesia.

[14] Indonesian Commercial Law.

[15] R. Subekti and R. Tjirosutjipto, Kitab Undang-undang Hukum Dagang dan Undang-undang Kepailitan, Jakarta: Pradnya Paramita, 1976.

[16] L. E. Ribstein, "The Deregulation of Limited Liability and the Death of Parnership," Wahington Uniersity Law Review, vol. 70, no. Symposium in Corporate Law and Finance, p. 424, 1992.

[17] C. Kansil, Hukum Perusahaan Indonesia, Jakarta: Pradnya Paramita, 1989.

[18] T. P. Moelion, Kekhawatiran Masa Kini (Pemikiran mengenai Hukum Pidana Lingkungan dalam Teori dan Praktek), Bandung: Citra Aditya, 1994.

[19] T. Ramadi, Hukum Lingkungan di Indonesia, Jakarta: PT RajaGrafindo Persada, 2011.

[20] D. Priyatno, Kebijakan Legislasi tentang Sistem Pertanggungjawaban Pidana Korporasi di Indonesia, Bandung: CV Utomo, 2004.

[21] V. Khanna, "Corporate Liability Standarts: When Should Corporate be Criminal Liable?," American Criminal Law Review, pp. 1242-1243, 2000.

[22] Hamdan, Alasan Penghapus Pidana (Teori dan Studi Kasus), Bandung: PT Refika Aditama, 2012.

[23] Z. A. Farid, Hukum Pidana I, Jakarta: Sinar Grafika, 2010.

[24] Establishment of Economic BPS Statistics Indonesia. 